Original Article

\title{
Genetic variations and phylogenetic relationship of genus Uromastyx from Punjab Pakistan
}

\author{
Variações genéticas e relação filgenética do gênero Uromastyx de Punjab, Paquistão

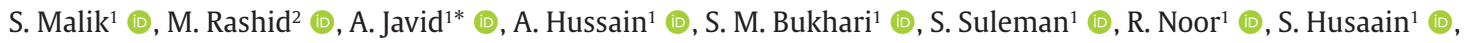 \\ N. Ismat ${ }^{3}$ (D), M. Hussain ${ }^{1}$ (D), S. Ghafoor ${ }^{1}$ (D) G. Mustafa ${ }^{1}$ (D) and W. Ali ${ }^{1}$ (D) \\ ${ }^{1}$ University of Veterinary and Animal Sciences, Department of Wildlife and Ecology, Lahore, Pakistan \\ ${ }^{2}$ University of Veterinary and Animal Sciences, Faculty of Fisheries and Wildlife, Lahore, Pakistan \\ ${ }^{3}$ The University of Lahore, Institue of Molecular Biology and Biotechnology - IMBB, Pakistan
}

\begin{abstract}
During the present study, specimens were collected from selected sites of Cholistan desert and Kalabagh Game Reserve, Punjab province, Pakistan. Each captured specimen was tagged with voucher number and morphometric measurements were taken. The average snout to vent length was $172.559 \pm 1.40 \mathrm{~mm}$ and average weight was $92.1 \pm 1.30 \mathrm{~g}$. The DNA of Uromastyx hardwickii was amplified and sequenced using $16 \mathrm{~S}$ rRNA primer set. The obtained DNA sequence has shown reliable and clear species identification. After trimming ambiguous bases, the obtained 16S rRNA fragment was 520 bp while 16S rRNA fragments aligned with closely matched sequence from NCBI comprised of $510 \mathrm{bp}$. Closely matched sequences of genus Uromastyx were retrieved from NCBI in blast searches. Neighbour-joining tree of genus Uromastyx was constructed based on p-distance using MEGA X. The mean intraspecific variation was $0.095 \pm 0.01$ while intraspecific variation was ranging from $0-1 \%$. Similarly, interspecific variation of Uromastyx hardwikii with Saara asmussi, Uromastyx alfredschmidti, Uromastyx geyri, Uromastyx thomasi, Uromastyx alfredschmidti was 0-12\%, 0-19\%, 0-19\%, 0-20\%, 12-19\% respectively. The newly produced DNA was submitted to NCBI and accession number was obtained (MW052563.1). Results of current study provided information about the molecular and morphological identification of Genus Uromastyx. In our recommendation, comprehensive molecular based identification of Pakistan's reptiles is required to report any new or subspecies from country.
\end{abstract}

Keywords: Kalabagh Game Reserve, Uromastyx hardwickii, Uromastyx asmussi, Palearctic region, IUCN redlist.

\begin{abstract}
Resumo
Durante o presente estudo, os espécimes foram coletados em locais selecionados do deserto do Cholistan e da Reserva de Caça de Kalabagh, província de Punjab, Paquistão. Cada espécime capturado foi etiquetado com o número do comprovante e medidas morfométricas foram realizadas. O comprimento médio do focinho à cloaca foi de $172,559 \pm 1,40 \mathrm{~mm}$, e o peso médio foi de $92,1 \pm 1,30$ g. O DNA de Uromastyx hardwickii foi amplificado e sequenciado usando o conjunto de primer $16 \mathrm{~S}$ rRNA. A sequência de DNA obtida mostrou identificação de espécies confiável e clara. Após o corte de bases ambíguas, o fragmento de rRNA 16S obtido tinha 520 pb, enquanto os fragmentos de rRNA $16 \mathrm{~S}$ alinhados com a sequência próxima do NCBI composta por $510 \mathrm{pb}$. Sequências semelhantes do gênero Uromastyx foram recuperadas do NCBI em pesquisas de explosão. A árvore de união de vizinhos do gênero Uromastyx foi construída com base na distância-p usando MEGA X. A variação intraespecífica média foi de $0,095 \pm 0,01$, enquanto a variação intraespecífica foi de $0-1 \%$. Da mesma forma, a variação interespecífica de Uromastyx hardwikii com Saara asmussi, Uromastyx alfredschmidti, Uromastyx geyri, Uromastyx thomasi, Uromastyx alfredschmidti foi de 0-12\%, 0-19\%, 0-19\%, 0-20\%, 12-19\%, respectivamente. 0 DNA recém-produzido foi submetido ao NCBI e o número de acesso foi obtido (MW052563.1). Os resultados do estudo atual forneceram informações sobre a identificação molecular e morfológica do Gênero Uromastyx. Em nossa recomendação, a identificação de base molecular abrangente de répteis do Paquistão é necessária para relatar qualquer nova ou subespécie do país.
\end{abstract}

Palavras-chave: Reserva de caça de Kalabagh, Uromastyx hardwickii, Uromastyx asmussi, região paleártica, lista vermelha da IUCN.

*e-mail: arshadjavid@uvas.edu.pk

Received: July 14, 2021 - Accepted: August 24, 2021 


\section{Introduction}

The changes that reptiles faced over millions of years results in massive diversity in their morphology, behavior, ecology history of life and in strategies against their predators. Due to all these features reptiles in terms of evolutionary and ecological research now become the central model system (Rasmussen et al., 2011). We used the term paraphyletic group for reptiles which include all non-avian taxa such as Sphenodontia, Squamata, Testudines and Crocodylia in this group. The total numbers of living reptile species are approximately 9546 , out of these the crocodiles are 25 (0.3\%), turtles are 327 (3.4\%) and tuatara is $1(0.01 \%)$ and the remaining $9,193(96.3 \%)$ are the squamates species (lizards, snakes and amphisbaenians) (Hay et al. 2010).

Reptiles are the mixture of Palearctic, Ethiopian and Indo-Malayan forms in Pakistan and are represented by 195 reptiles, and consists of 23 families including Dermochelyidae, Cheloniidae, Emydidae, Testudinidae, Trionychidae, Gavialidae, Crocodylidae, Agamidae, Chameleonidae, Gekkonidae, Eublepharidae, Scincidae, Lacertidae, Varanidae, Uromastycidae, Typhlopidae, Leptotyphlopidae, Colubridae, Boidae, Elapidae, Hydrophiidae, Elapidae, Crotalidae and Viperidae (Khan et al.2010). Out of these thirteen species are endemic to country. The Lizards are the prominent group of reptiles in Pakistan and represented by eight families viz., Scincidae, Uromastycidae, Varanidae, Agamidae, Chamaeleonidae, Eublepharidae, Lacertidae and Gekkonidae (Khan, 2004, 2006). According to IUCN (IUCN Red List of Threatened Species, 2009) 1,677 reptiles are included in Red List. Out of these, 469 species are near to extinction and 22 are already extinct. Furthermore, only $40 \%$ of reptiles' species have their Conservation status and about 4,000 were not assessed yet (IUCN Red List of Threatened Species, 2009).

The identification and taxonomic classification of reptiles is very challenging task. Recently, a molecular technique which is used for the identification is known as DNA barcoding which is used for finding phylogenetic relationships. Before 2005 DNA barcoding of amphibians and reptiles was very difficult as compared to other taxa such as fishes, birds and mammals (Hebert et al., 2004). In DNA barcoding, a short sequence of DNA is compared with reference database for the identification of species (Hajibabaei et al., 2007). The genomic regions that are mostly used include 12S rRNA, 16S rRNA, Cytb and COI consisting on 600-1200 bp (Hebert et al., 2003; Nagy et al., 2012).

Habitat loss and illegal trading have effect the survival and existence of many reptile species worldwide especially in Pakistan. One of them is Indian spiny-tailed lizard (Uromastyx hardwickii). The U. hardwickii is medium to large size lizard reported from North Africa to North Western Indian desert. Spiny tailed lizard is ground dweller and herbivorous. In Pakistan, it is distributed in Southern Baluchistan, Indus valley, extended to Las bela and Chagai desert. The major threats to this species are its commercial exploitation for meat, skin and oil. About 367,000 specimens were legally traded between 1977 and 2005 (Knapp, 2004).

Genus Uromastyx is represented by 17 species. Most of species within genus Uromastyx were identify on the basis of external morphology and heir phylogenetic relationship is still under debate (Amer and Kumazawa, 2005; Wilms and Schmitz, 2007). Pakistan is represented by two species of genus Uromastyx namely Uromastyx hardwickii and Uromastyx asmussi. Present study was therefore planned to identify members of genus Uromastyx through mitochondrial genes and sort out taxonomy problems of these taxa.

\section{Materials and methods}

\subsection{Sample collection}

A total of 10 specimens are collected from selected sites of Cholistan desert and Kalabagh Game Reserve, Punjab province. Each captured specimen was tagged with voucher number and morphometric measurements were taken following Ali et al.(2017). A few specimen of each sampling site $(n=3)$ were euthanized and preserved in $75 \%$ ethanol for molecular characterization.

\subsection{Morphometric measurement}

The following morphometric measurement were taken $\mathrm{SVL}=$ snout vent length, $\mathrm{TAL}=$ tail length, $\mathrm{HL}=$ head length, $\mathrm{HW}=$ head width, BW=body width, IIL=interlimb length, $\mathrm{FC}=$ fore claw length, $\mathrm{HC}$ =hind claw length, $\mathrm{HLS}$ =hind limb Span, FLS=forelimb span, HLF=hind limb longest finger, $\mathrm{FLF}=$ forelimb longest finger, $\mathrm{W}=$ weight and $\mathrm{TL}=$ total length (Ali et al. 2017).

\subsection{DNA extraction and amplification}

DNA was extracted using phenol chloroform method (Ali et al., 2020). The quality of DNA was checked on $1.5 \%$ agarose gel in the post-graduate lab, Department of Wildlife and Ecology, University of Veterinary and Animal Sciences, Pakistan. The amplification was done by using cytochrome oxidase I (COI) and 16S rRNA primers sets. PCR reaction was performed in $0.2 \mathrm{ml}$ PCR tube and $25 \mu \mathrm{L}$ reaction mixtures. To prepare $25 \mu \mathrm{L}$ reaction mix $6 \mu \mathrm{L}$ double distilled water, $1 \mu \mathrm{L}(25 \mathrm{mM})$ Primer F, $1 \mu \mathrm{L}(25 \mathrm{mM})$ primer R, $12 \mu \mathrm{L}$ Master mix and $5 \mu \mathrm{L}$ of DNA template was mixed. In each reaction a negative control was also run using sterilized water as the template. The following steps were performed forthe amplification of gene, 3 minutes denaturing at $94^{\circ} \mathrm{C}$ followed by 40 cycles of for $30 \mathrm{sec}$ at $94^{\circ} \mathrm{C}$, primer annealing for $30 \mathrm{sec}$ at $42-55^{\circ} \mathrm{C}$ depend on the primer's annealing temperature and elongation for 1 minutes at $72^{\circ} \mathrm{C}$, with final 10 minutes at $72^{\circ} \mathrm{C}$ and infinity at $4^{\circ} \mathrm{C}$ (Ali et al., 2020; Vences et al., 2005). PCR products were checked on $1.5 \%$ agarose gels and products were purified by using the Qiagen purification kit and all the samples were sequenced in both directions using dideoxy chain termination direct Sanger sequencing on ABI3730XL DNA Analyzer. The newly obtained DNA sequences were submitted to Gen bank for accession numbers.

\subsection{Data analysis}

The obtained DNA sequences were analyzed and edited in Bioedit software 7.0 and aligned using Clustal X 
(Hussain et al., 2020; Tamura et al., 2013).The consensus sequence of each sample were subjected to BLAST (basic local alignment tool search) analysis to compare the percentage identity of sequence by searching in the public DNA databases. The closely related sequences were obtained and incorporated in the neighbor-joining ( $\mathrm{NJ}$ ) tree analyses with bootstrap value of 100 replicates using MEGA 10. Genetic distances within and between species were calculated using Mega 6.0 based on p-distance.

\section{Results}

The specimens of Uromastyx hardwickii (Figure 1) were collected from selected sites of District Bahawalnagar and Kalabagh Game Reserve, Punjab province, Pakistan (Figure 2) during field surveys extended from May to August, 2020.

\subsection{Morphological identification and measurements}

The average snout to vent length was $172.559 \pm 1.40 \mathrm{~mm}$, tail length was $126.55 \pm 0.9 \mathrm{~mm}$, head length was $33.05 \pm 1.9$, head width was $24.75 \pm 1.1$, body weight was $42.6 \pm 1.4$, IIL was $33.175 \pm 1.6$, FC was $18.675 \pm 1.1$, HC was $27.525 \pm 1.4$, HLS was $126.525 \pm 1.2$, FLS was $17.625 \pm 0.8$, HLF was $17.625 \pm 0.8$, FLS was $12.1 \pm 2.2$ and average weight was $92.1 \pm 1.30 \mathrm{~g}$ (Table 1$)$.

The description of captured specimens from study area is as follows;

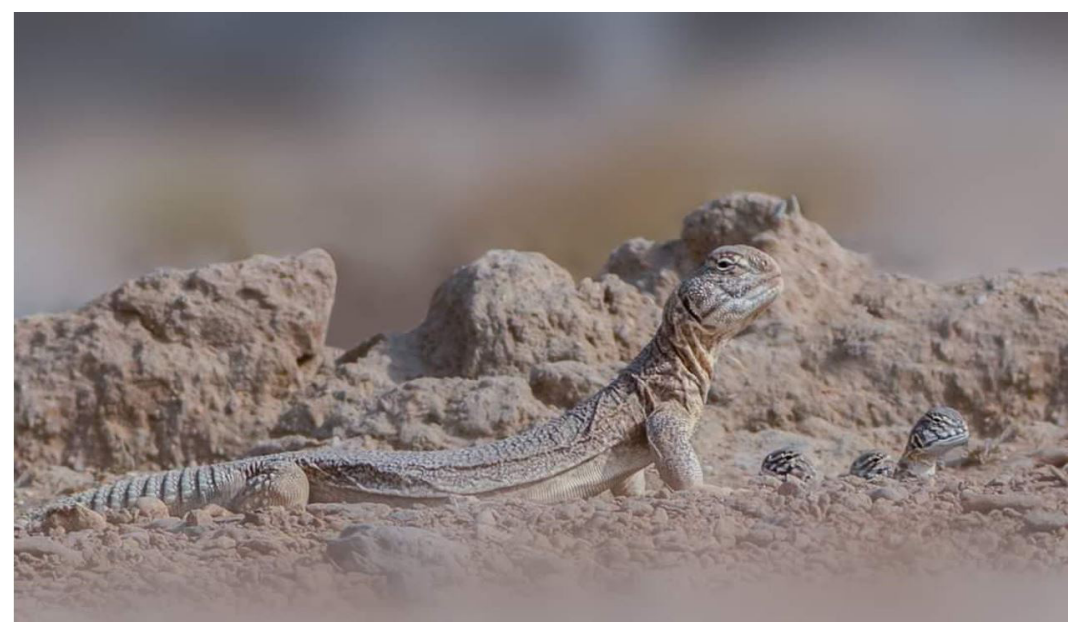

Figure 1. Uromastyx hardwickii captured from District Bahawalnagar and Kalabagh Game Reserve, Punjab province, Pakistan.

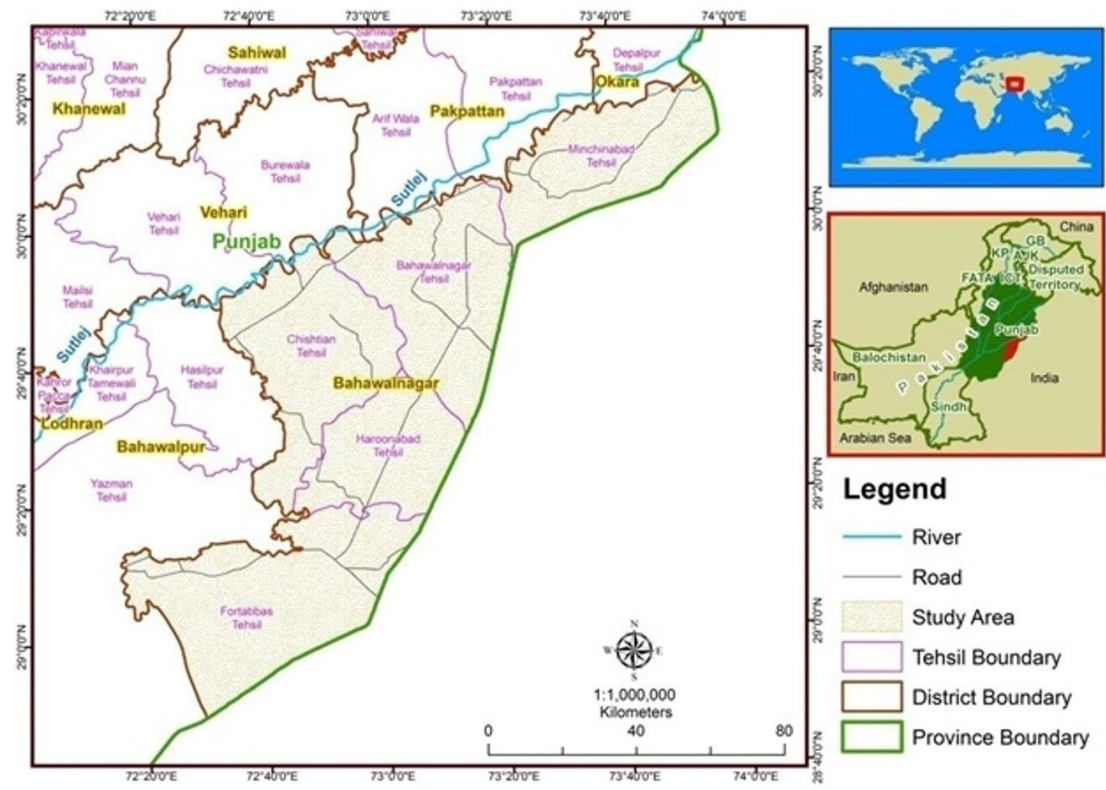

Figure 2. Map of study area. 


\section{Genus Uromastyx (Merrem, 1820)}

The subfamily Uromastycinae consist of two genera Saara Gray, 1845 and Uromastyx Merrem, 1820 Within the Uromastycinae. Uromastyx is the largest genus its habitat is desert and semi desert area with the passage of years it's taxonomy has been changed since 1980 it include four species and three subspecies. The members of Uromastycinae are commonly called spiny tail lizard as their tail is covered with spines. On the basis of presence and absence of inter-calaries between the tail and whorls two genera saara and Uromastyx is differentiated. Pakistan is represented by two species of genus Uromastyx namely Uromastyx hardwickii and Uromastyx asmussi.

i. Uromastyx hardwickii

Uromaastyx hardwickii commonly called spiny tailed lizard and found in dry regions of northwest India and Pakistan also found in Afghanistan its maximum SVL is $233 \mathrm{~mm}$. Around the mid body 190-275 scales are found and 24-42 scales are present near the ear opening on the fourth left toe 15-21 scales are present. On the either side 12-19 pre-anofemoral pores are present. Between the gular- and inguinal fold 112-157 scales are present. The $U$. hardwickii is medium to large size lizard reported from North Africa to North Western Indian desert. Spiny tailed lizard is ground dweller and herbivorous. In Pakistan, it is distributed in Southern Baluchistan, Indus valley, extended to Las bela and Chagai desert. The major threats to this species are its commercial exploitation for meat, skin and oil. About 367,000 specimens were legally traded between 1977 and 2005.

\subsection{Amplification and sequencing}

During present study, DNA of Uromastyx hardwickii was amplified and sequenced using 16S rRNA primer set. The obtained DNA sequence has shown reliable and clear species identification. After trimming ambiguous bases, the obtained 16S rRNA fragment of Uromastyx hardwickii was 520 bp while 16SrNRA fragments aligned with NCBI sequences comprised $510 \mathrm{bp}$ (Table 2 ). The newly produced DNA was submitted to NCBI and accession number was obtained (MW052563.1).

\subsection{Genetic diversity and variation}

The mean intraspecific variation was $0.095 \pm 0.019$ while intraspecific variation of Uromastyx Hardwikii was ranging from 0-1\%. Similarly, interspecific variation of Uromastyx hardwikii with Saara asmussi, Uromastyx alfredschmidti, Uromastyx geyri, Uromastyx thomasi, Uromastyx alfredschmidti was 0-12\%, 0-19\%, 0-19\%, 0-20\%, 12-19\% respectively (Table 3 ).

\subsection{Phylogenetic analysis}

Recently few DNA barcoding studies of Asian amphibians and reptiles have been carried out and sequences for related species were available at NCBI. Closely matched sequences

Table 1. Weight $(\mathrm{g})$ and external body measurements ( $\mathrm{mm}$ ) of Uromastyx hardwickii captured from study area.

\begin{tabular}{|c|c|c|c|c|c|c|c|c|c|c|c|}
\hline 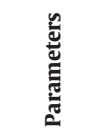 & 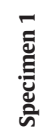 & 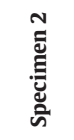 & 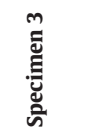 & 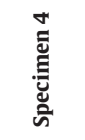 & 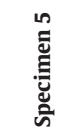 & 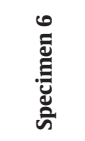 & 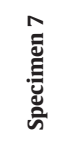 & 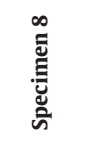 & 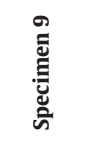 & 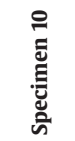 & 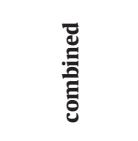 \\
\hline SVL (mm) & 170 & 171 & 171.5 & 172 & 172.5 & 173 & 173.5 & 173.59 & 174 & 174.5 & $172.559 \pm 1.40$ \\
\hline TAL & 127 & 126 & 125 & 125.5 & 126 & 126.5 & 127 & 127.5 & 127 & 128 & $126.55 \pm 0.90$ \\
\hline HL & 33 & 32 & 30 & 31 & 31.5 & 33 & 34.5 & 34.5 & 35 & 36 & $33.05 \pm 1.90$ \\
\hline HW & 23 & 23.5 & 23.75 & 24 & 24.5 & 25 & 25.5 & 25.75 & 26 & 26.5 & $24.75 \pm 1.10$ \\
\hline BW & 40 & 41 & 41.5 & 42 & 42.5 & 43 & 43.5 & 44 & 44.5 & 44 & $42.6 \pm 1.40$ \\
\hline IIL & 30 & 31 & 32 & 33 & 33.5 & 34 & 34 & 34.5 & 34.75 & 35 & $33.175 \pm 1.06$ \\
\hline FC & 17 & 17.5 & 17.75 & 18 & 18.5 & 19 & 19 & 19.5 & 20 & 20.5 & $18.675 \pm 1.10$ \\
\hline HC & 25 & 26 & 27.5 & 27.75 & 28 & 28.5 & 29 & 29.5 & 28 & 26 & $27.525 \pm 1.40$ \\
\hline HLS & 125 & 125.5 & 126 & 126.5 & 127 & 126 & 127.75 & 128 & 128.5 & 125 & $126.525 \pm 1.20$ \\
\hline FLS & 100 & 99 & 99.5 & 98 & 98.5 & 98.75 & 99 & 95 & 99 & 97 & $98.375 \pm 1.40$ \\
\hline HLF & 17 & 16 & 17.5 & 18 & 18.5 & 16.75 & 16.75 & 18 & 19 & 18.5 & $17.625 \pm 0.80$ \\
\hline FLF & 12 & 10 & 12 & 11 & 9 & 10 & 12 & 14 & 15 & 16 & $12.1 \pm 2.20$ \\
\hline $\mathrm{W}(\mathrm{g})$ & 90 & 91 & 90.5 & 91.5 & 92.5 & 93 & 93 & 93.5 & 93 & 94 & $92.1 \pm 1.30$ \\
\hline
\end{tabular}

Table 2. The details of successful amplified specimens and Genbank accession number.

\begin{tabular}{ccccc}
\hline Genus & Family & Species & Voucher number & $\begin{array}{c}\text { GenBank accession } \\
\text { number }\end{array}$ \\
\hline Uromastyx & Agamidae & Uromastyx hardwickii & ZMUVAS40 & MW052563.1 \\
\hline
\end{tabular}


Table 3. Intraspecific and interspecific variations of genus Uromastyx calculated using p-distance based on 16S rRNA gene.

\begin{tabular}{|c|c|c|c|c|c|c|c|c|c|c|c|c|}
\hline \multirow{2}{*}{ Speci } & & \multicolumn{4}{|c|}{ 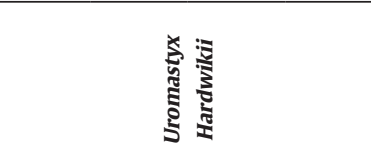 } & \multirow{2}{*}{ 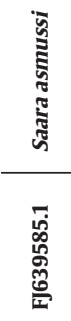 } & \multicolumn{3}{|c|}{ 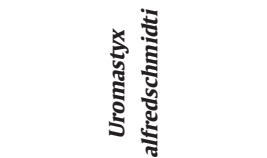 } & \multirow{2}{*}{ 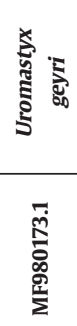 } & \multicolumn{2}{|c|}{ 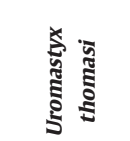 } \\
\hline & & 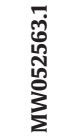 & 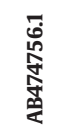 & 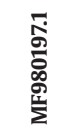 & 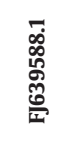 & & 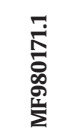 & 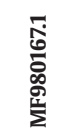 & 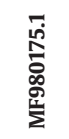 & & 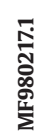 & 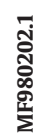 \\
\hline \multirow{4}{*}{$\begin{array}{l}\text { Uromastyx } \\
\text { Hardwikii }\end{array}$} & MW052563.1 & ID & & & & & & & & & & \\
\hline & AB474756.1 & 1 & ID & & & & & & & & & \\
\hline & MF980197.1 & 0.998 & 0.998 & ID & & & & & & & & \\
\hline & FJ639588.1 & 0.998 & 0.998 & 1 & ID & & & & & & & \\
\hline \multirow{4}{*}{$\begin{array}{c}\text { Saara asmussi } \\
\text { Uromastyx } \\
\text { alfredschmidti }\end{array}$} & FJ639585.1 & 0.883 & 0.883 & 0.885 & 0.885 & ID & & & & & & \\
\hline & MF980171.1 & 0.818 & 0.818 & 0.817 & 0.817 & 0.854 & ID & & & & & \\
\hline & MF980167.1 & 0.818 & 0.818 & 0.817 & 0.817 & 0.854 & 1 & ID & & & & \\
\hline & MF980175.1 & 0.818 & 0.818 & 0.817 & 0.817 & 0.854 & 1 & 1 & ID & & & \\
\hline \multirow{3}{*}{$\begin{array}{c}\text { Uromastyx geyri } \\
\text { Uromastyx } \\
\text { thomasi }\end{array}$} & MF980173.1 & 0.818 & 0.818 & 0.817 & 0.817 & 0.858 & 0.977 & 0.977 & 0.977 & ID & & \\
\hline & MF980217.1 & 0.807 & 0.807 & 0.805 & 0.805 & 0.845 & 0.893 & 0.893 & 0.893 & 0.897 & ID & \\
\hline & MF980202.1 & 0.807 & 0.807 & 0.805 & 0.805 & 0.845 & 0.893 & 0.893 & 0.893 & 0.897 & 1 & ID \\
\hline
\end{tabular}

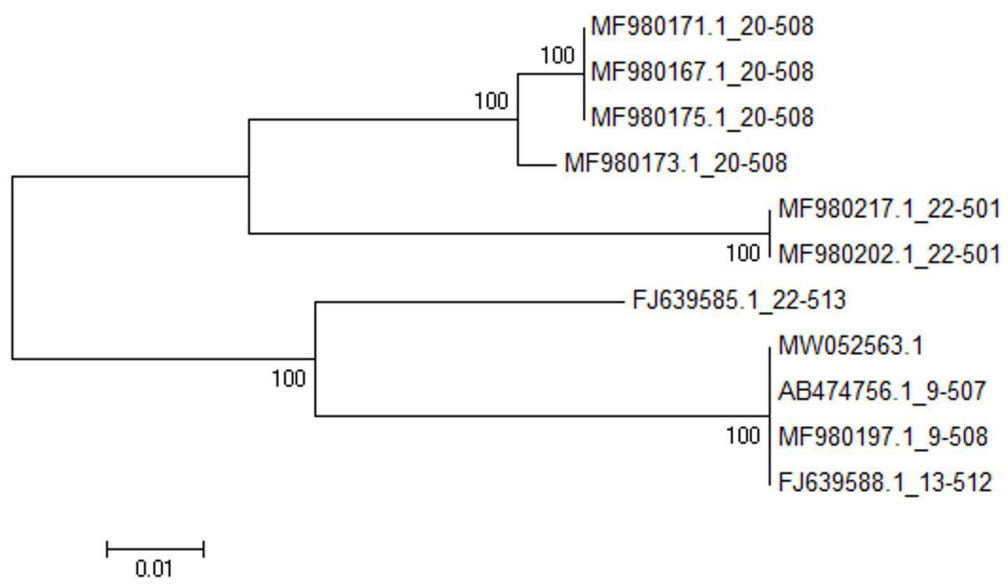

Figure 3. $\mathrm{N}$-j tree of genus Uromastyx.

of genus Uromastyx were retrieved from NCBI in blast searches. Neighbour-joining tree of genus Uromastyx was constructed based on 16S rRNA sequence using MEGA X (Figure 3). The analysis involved 11 nucleotide sequences. All ambiguous positions were removed for each sequence pair. There were a total of 510 positions in the final dataset.

\section{Discussion}

The information related to DNA barcoding of reptiles is very less as compared to other animals. The genes that are used for this purpose is Cytochrome C Oxidase I(COI), cytochrome b (Cytb), 12S rRNA and 16S rRNA (Nicolas et al., 2012; Xia et al., 2012). In the past due to the problems that researcher faced in case of COI sequences amplification and evaluation of reptiles and amphibians prefer to use the $16 \mathrm{~S}$ ribosomal RNA gene for DNA barcoding. Vasconcelos et al. (2016) used COI gene to find the intra-specific of reptiles which was ranging between $13.8-54.4 \%$. Sharma et al. (2018) isolate the DNA from the feces of Indian Spiny Tailed Lizard Saara hardwickii. They carried out research in Rajasthan in June 2016 and used the 16S rRNA gene in order to find out genetic variation in S. hardwickii. Phylogenetic relationship indicated that due to illegal trading, India and 
global samples shared ancestry as at seven bp insertion (126-128) and deletion present at 2(49-252).

Arida (2017) used different mitochondrial DNA regions for the identification of monitor lizard in Indonesia. Previous Studies on the Varanus genus shows that the mitochondrial markers that were used on the biogeography and on systematics were $12 \mathrm{~S}$ rRNA and $16 \mathrm{~S}$ rRNA. The combination of nuclear and mitochondrial genes also used by others (Ziegler et al., 2007; Fuller et al., 1998; Fitch et al., 2006; Douphty et al., 2014; Francis et al., 2010; Nagy et al., 2012).

Adam et al. (2009) used mitochondrial DNA sequences of about $1,181 \mathrm{bp}$ to described phylogeny of nineteen species of African lizards. The species of East and West Africa has monophyletic radiations which were supported along with a clade that contain 2 species of sahel region.

\section{Conclusions and recommendations}

During present study, different mitochondrial genes COI and 16S rRNA were used to identify genus Uromastyx from study area. The DNA of Uromastyx Hardwikii successfully amplified using 16S rRNA primer set. Results of current study provided information about the molecular and morphological identification of Genus Uromastyx. Comprehensive molecular based identification of Pakistan's reptiles is required to report any new or subspecies from country.

\section{References}

ADAM, D., REBECCA, A., THEODORE, J., PHILIPP, W., WOLFGANG, B., ANDREAS, S., MARK, O. R., MATTHEW, L., IVAN, I., LAURENT, C., AARON, B., EDEM, A.E., and SHERIF, B.E., 2009. Phylogeny of the genus Agama based on mitochondrial DNA sequence data. Bonner zoologische Beitrage, vol. 56, no. 4, pp. 273-278.

ALI, W., JAVID, A., HUSSAIN, A., HAFEEZ-UR-REHMAN, M., CHABER, A. L., and HEMMATZADEH, F., 2020. First record of Euphlyctis kalasgramensis (Anura: Dicroglossidae) from Punjab, Pakistan. Mitochondrial DNA Part B, vol. 5, no. 2, pp. 1227-1231.

ALI, W., JAVID, A., KHAN, W. A., HUSSAIN, A., RIZWAN, M., AMEER, M., and SAJID, A.Q., 2017. Diversity and habitat preferences of herpetofauna at Kalabagh game reserve, District Mianwali, Punjab, Pakistan. Russian Journal of Herpetology, vol. 24, no. 4, pp. 267-274.

AMER, S.A.M. and KUMAZAWA, Y., 2005. Mitochondrial DNA sequences of the Afro-Arabian spiny-tailed lizards (genus Uromastyx; family Agamidae): phylogenetic analyses and evolution of gene arrangements. Biological Journal of the Linnean Society. Linnean Society of London, vol. 85, no. 2, pp. 247-260. http://dx.doi.org/10.1111/j.1095-8312.2005.00485.x.

ARIDA, E., 2017. Genetic divergence and phylogenetic relationship among indonesian specie of monitor lizards of the genus Varanus based on cytochrome oxidase I sequences. Hayati Journal of Biosciences, vol. 24, no. 1, pp. 41-45. http://dx.doi. org/10.1016/j.hjb.2017.05.003.

DOUPHTY, P., KEALLEY, I., FITCH, A. and DONNELAN, S.C., 2014. A new diminutive species of Varanus from the Dampier Penisula, Western Kimberley region, Western Australia. Records of the Western Australian Museum, pp. 128-140. http://dx.doi. org/10.18195/issn.0312-3162.29(2).2014.128-140.
FITCH, A.J., GOODMAN, A.E. and DONNELLAN, S.C., 2006. A molecular phylogeny of the Australian monitor lizards (Squamata:Varanidae) inferred from mitochondrial DNA sequences. Australian Journal of Zoology, vol. 54, no. 4, pp. 253-269. http://dx.doi.org/10.1071/ZO05038.

FRANCIS, C.M., BORISENKO, A.V., IVANOVA, N.V., EGER, J.L., LIM, B.K., GUILLÉN-SERVENT, A., KRUSKOP, S.V., MACKIE, I. and HEBERT, P.D.N., 2010. The role of DNA barcode in Understanding and conservation of mammal divergence in Southeast Asia. PLoS One, vol. 5, no. 9, pp. e12575. http://dx.doi.org/10.1371/journal. pone.0012575. PMid:20838635.

FULLER, S., BAVERSTOCK, P. and KING, D., 1998. Biogeographic origins of goannas (Varanidae): a molecular perspective. Molecular Phylogenetics and Evolution, vol. 9, no. 2, pp. 294-307. http:// dx.doi.org/10.1006/mpev.1997.0476. PMid:9562987.

HAJIBABAEI, M., SINGER, G.A.C., HEBERT, P.D.N. and HICKEY, D.A., 2007. DNA barcoding: how it complements taxonomy, molecular phylogenetic and population genetics. Trends in Genetics, vol. 23, no. 4, pp. 167-172. http://dx.doi.org/10.1016/j. tig.2007.02.001. PMid:17316886.

HAY, J.M., SARRE, S., LAMBERT, D., ALLENDORF, F. and DAUGHERTY, C., 2010. Genetic diversity and taxonomy: a reassessment of species designation in tuatara (Sphenodon: Reptilia). Conservation Genetics, vol. 11, no. 3, pp. 1063-1081. http:// dx.doi.org/10.1007/s10592-009-9952-7.

HEBERT, P.D., CYWINSKA, A., BALL, S.L. and DEWAARD, J.R., 2003. Biological identifications through DNA barcodes. Proceedings. Biological Sciences, vol. 270, no. 1512, pp. 313-321. http://dx.doi. org/10.1098/rspb.2002.2218. PMid:12614582.

HEBERT, P.D.N., PENTON, E.H., BURNS, J.M., and JANZEN, D.H., 2004. Ten species in one: DNA barcoding reveals Cryptic Species in the neotropical skipper butterfly Astroptes fulgerator. Proceedings of the National Academy of Sciences of the United States of America, vol. 101, no. 41, pp. 14812-14817. http://dx.doi.org/10.1073/ pnas.0406166101.

HUSSAIN, S., BUKHARI, S.M., JAVID, A., HUSSAIN, A., RASHID, M., and ALI, W., 2020. Molecular identification of genus Duttaphrynus from Punjab, Pakistan. Mitochondrial DNA Part B, vol. 5, no. 3, pp. 3218-3220.

IUCN RED LIST OF THREATENED SPECIES. Reptiles facts. IUCN, 2009, pp. 1-180.

KHAN, M.S., 2004. Annotated checklist of amphibians and reptiles of Pakistan. Asian Herpetological Research, vol. 10, pp. 191-201.

KHAN, M.S., 2006. Amphibians and reptiles of Pakistan. Malabar, Florida, USA: Krieger Publishing Company, pp. 1-311.

KHAN, M.Z., HUSSAIN, B., GHALIB, S.A. and ZEHRA, A.M.N., 2010. Distribution, population status and environmental impacts on reptiles in Manora, Sandspit, Hawkesbay and Cape Monze areas of Karachi coast. Pure E Applied Sciences (Basel, Switzerland), vol. 4, pp. 105371.

KNAPP, A., 2004. An Assessment of the International Trade in Spinytailed Lizards Uromastyx with a Focus on the Role of the European Union. Technical Report to the European Commission. Europe: European Commission.

NAGY, Z.T., SONET, G., GLAW, F. and VENCES, M., 2012. First largescale DNA barcoding assessment of reptiles in the biodiversity hotspot of Madagascar, based on newly designed COI primers. PLoS One, vol. 7, no. 3, pp. e34506. http://dx.doi.org/10.1371/ journal.pone.0034506. PMid:22479636.

NICOLAS, V., SCHAEFFER, B., MISSOUP, A.D., KENNIS, J., COLYN, M., DENYS, C., TATARD, C., CRUAUD, C. and LAREDO, C., 2012. Assessment of Three Mitochondrial Genes (16S, Cytb, C01) for Identifying Species in the Praomyini Tribe (Rodentia: muridae). 
PLoS One, vol. 7, no. 5, pp. e36586. http://dx.doi.org/10.1371/ journal.pone.0036586.

RASMUSSEN, A.R., MURPHY, J.C., OMPI, M., GIBBONS, J.W. and UETZ, P., 2011. Marine reptiles. PLoS One, vol. 6, no. 11, pp. 27373. http:// dx.doi.org/10.1371/journal.pone.0027373. PMid:22087300.

SHARMA, C., DAS, A., MOHANTY, S., SINGH, U.S. and DAS, S.K., 2018. DNA sequence monomorphism of Indian spiny tailed lizard Saara hardwickii suggests urgent conservation. Journal of Entomology and Zoology, vol. 6, pp. 1547-1551.

TAMURA, K., STECHER, G., PETERSON, D., FILIPSKI, A. and KUMAR, S., 2013. MEGA6: molecular evolutionary genetics analysis version 6.0. Molecular Biology and Evolution, vol. 30, no. 12, pp. 2725-2729. PMid:24132122.

VASCONCELOS, R., MENDIETA, M.S., RIUDALBAS, S.M., SINDACO, R., SANTOS, X., FASOLA, M., LLORENTE, G., RAZZETTI, E. and CARRANZA, S., 2016. Unexpectedly high levels of cryptic diversity uncovered by a complete DNA Barcoding of Reptiles of the Socotra Archipelago. PLoS One, vol. 11, no. 3, pp. 0149985. http://dx.doi.org/10.1371/journal.pone.0149985. PMid:26930572.
VENCES, M., THOMAS, M., BONETT, R.M. and VIEITES, D.R., 2005. Deciphering amphibian diversity through DNA barcoding: chances and challenges. Philosophical Transactions of the Royal Society of London. Series B, Biological Sciences, vol. 360, no. 1462, pp. 18591868. http://dx.doi.org/10.1098/rstb.2005.1717. PMid:16221604.

WILMS, T. and SCHMITZ, A., 2007. A new polytypic species of the genus Uromastyx Merrem, 1820 (Reptilia: Squamata: Agamidae: Leiolepidinae) from southwestern Arabia. Zootaxa, vol. 1394, no. 1, pp. 1-23. http://dx.doi.org/10.11646/zootaxa.1394.1.1.

XIA, Y., GU, H., PENG, R., CHEN, Q., ZHENG, Y.C., MURPHY, R.W. and ZENG, X.M., 2012. COI is better than 16S rRNA for DNA barcoding Asiatic salamanders (Amphibia: Caudata: Hynobiidae). Molecular Ecology Resources, vol. 12, no. 1, pp. 48-56. http:// dx.doi.org/10.1111/j.1755-0998.2011.03055.x. PMid:21824335.

ZIEGLER, T., SCHMITZ, A., KOCH, A. and BOHME, W., 2007. A review of the Subgenus Euprepio-saurus of Varanus (Squamata: Varanidae): morphological and molecular phylogeny, distribution and Zoogeography with an Identification key for the members of the $V$. Indicus and the $V$. prasinus species groups. Zootaxa, vol. 1472, no. 1, pp. 1-28. http://dx.doi.org/10.11646/zootaxa.1472.1.1. 